\title{
Neuroaprendizaje, una propuesta educativa: herramientas para mejorar la praxis del docente ${ }^{1}$
}

\section{Neurolearning, an educational proposal: tools to improve teacher praxis}

Recibido: 25 de agosto de 2016. Revisado: 11 de diciembre de 2016. Aceptado: 27 de marzo de 2017.

\author{
Gustavo Pherez ${ }^{2}$ \\ Sonia Vargas ${ }^{3}$ \\ Jessica Jerez ${ }^{4}$
}

\section{Resumen}

Este estudio tiene como objetivo proponer estrategias pedar,jgici innovaa is paia los procesos de enseñanza-aprendizaje de los programas de 1 Facultad de Educa on de la Corporación Universitaria Adventista, donde se apliquen rocesos desde la base del neuroaprendizaje y la neuroeducación y es derivado de uná vvestigación ' con enfoque cualitativo y de tipo documental. Para la búsqueda, re ción y anáı de la l'. eratura se aplicó

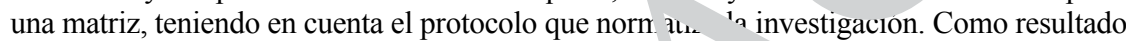
del estudio se observa que hoy en el aula, desde la mirc la dr la ' rrseducación, la educación demanda una formación docente que ge cambios celeradss para ejercer la enseñanza y vincule los aportes neurocientíficr con la ráctica p dagógica. La investigación permite concluir que la nueva tendencia romp el $\mathrm{m}$. delo del $\mathrm{p}$. ofesor tradicional, constituyéndolo en un neuroeducador y al a $a_{1}$ car las $\epsilon$. tteglas ... la neurociencia a la neuroeducación, se favorece la enseñanz y pueden o ner mejores resultados en el momento de la adquisición, retención y aplica $\eta$ del aprer sıaje en el educando.

\section{Palabras clav}

Neurociencias gnitavas, neuroeducación, neuroaprendizaje, neurodidáctica, praxis docente estrateg, pedagóg cas.

\section{1. tract}

The $m$ - is study is to propose innovative pedagogical strategies for the teachinglearnit. processes with a Neurolearning and Neuroeducation base for the programs in the Educ : ${ }_{n}$ Faculty in the Corporation Colombian University Adventist. This article has a qua.itative and documentary approach. For the search, review and analysis of the literature, we applied a matrix with a protocol to regulate the research. As a result of the study, we observed from the neuroeducation perspective that currently in classroom, education demands a qualify teacher training to accelerate changes in teaching practice and to link acording to neuroscientific contributions with pedagogical approach. This investigation concludes that this new tendency breaks with the traditional model of the professor, and constitutes him/her as a neuroeducator. Applying the Neuroscience strategies to Neuroeducation favors teaching and it can obtained better results in the acquisition, retention and application of student learning process.

\section{Keywords}

Cognitive neurosciences, neuroeducation, neurolearning, neurodidactics, teaching praxis, pedagogical strategies.
${ }^{1}$ Artículo derivado una investigación con enfoque cualitativo y de tipo documental realizada por la Corporación Universitaria Adventista.

${ }^{2}$ Decano y docente de la Facultad de Educación. Doctorando en Ciencia de la Educación de la Universidad de Rosario, Argentina. Magister en Educación Mención Docencia, de la Universidad Adventista de Chile, Magister de Ministerio Pastoral del Seminario Bíblico Interamericano, SETAI, con sede en Puerto Rico. Investigador del Grupo de Investigación: Pedagogía, Cultura y Sociedad de la Corporación Universitaria Adventista, Medellín, Colombia. Correo electrónico: gpherez@unac.edu.co

${ }^{3}$ Coordinadora Licenciatura en Preescolar. Docente Facultad de Educación. Mg. En Neuropsicología Educativa. Especialista en Pedagogía e Investigación en el Aula. Investigadora del grupo Pedagogía Cultura y Sociedad de la Facultad de Educación. Líder de la Línea Pedagogía e Infancia de la Corporación Universitaria Adventista, Medellín, Colombia. Correo electrónico: svargas@unac. edu.co.

${ }^{4}$ Psicóloga- esp. en Psicología de las Organizaciones y del Trabajo-Universidad de San Buenaventura. Docente e investigadora del grupo Pedagogía Cultura y Sociedad de la Facultad de Educación-Corporación Universitaria Adventista, Medellín, Colombia. Correo electrónico: docente.jjerez@ unac.edu.co

Para citar este artículo use: Pherez, G., Vargas, S., y Jerez., J. (2018) Neuroaprendizaje, una propuesta educativa: herramientas para mejorar la praxis del docente. Revista Civilizar, 18(34), 149-166. 